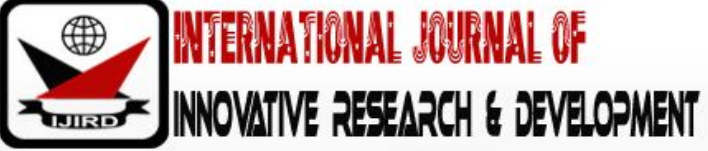

ISSN 2278 - 0211 (Online)

\section{Factors Affecting Undergraduate Students' Performance in Mathematics in Rivers State Tertiary Institutions Nigeria}

\begin{tabular}{c}
\hline Dr. George, Nchelem Rosemary \\
Senior Lecturer, Department of Mathematics/ Statistics, \\
Ajuru University of Education, Port Harcourt, Nigeria \\
Zalmon Ibaan Gogo \\
Lecturer, Department of Mathematics/ Statistics, \\
Ajuru University of Education, Port Harcourt, Nigeria \\
Okafor Chiamaka P. \\
Student, Department of Mathematics/ Statistics, \\
Ajuru University of Education, Port Harcourt, Nigeria \\
\hline
\end{tabular}

\begin{abstract}
:
The study investigated the factors affecting undergraduate students' performance in Mathematics in Rivers State, Nigeria. The study adopted the analytical survey design. The population of the study consisted of seven hundred and fifty-five (755) undergraduate Mathematics students from the Department of Mathematics of the three Universities in Rivers State. A sample of 249 Mathematics undergraduates was selected via stratified random sampling technique. Two researcher developed instruments: Factors Affecting Undergraduate Students' Mathematics Performance Questionnaire (FAUSMPQ) and Algebra Performance Test (APT) were used for data collection. The reliability indices of FAUSMPQ $(r=$ $0.70)$ and APT $(r=0.76)$ were established using test retest method and Pearson's Product Moment Correlation (PPMC) statistic. Data collected were analyzed using mean, standard deviation, PPMC and regression analysis. Mean and standard deviation were used to answer research questions one to five while PPMC was used to answer research question six. The six hypotheses of the study were tested using regression analysis. The study found out that the lecturer, student and parental factors have significant positive relationship while school and governmental factors have insignificant but positive relationship with undergraduate students' performance in Mathematics. The study recommended among others that the government and the school management should effectively manage the lecturers, students and collaborate with the parents to ensure improved undergraduate students' performance in Mathematics.
\end{abstract}

Keywords: Undergraduate student, factors, affecting, performance, mathematics

\section{Introduction}

Our society requires adequate human and material resources to improve its social organization, preserve its culture, enhance economic development and reform the political structures. This required manpower for national development is a product of education. Education is an instrument for national and social change which maximizes the creative potentials and skills of the individual for self-fulfillment and general development of the society (Federal Republic of Nigeria (FRN), 2014). Education is often seen as the prerequisite for quality manpower development and creation of wealth, a sure path to success in life and service to humanity. In a general sense, education is a form of learning in which the knowledge, skills, values, ideas, norms, morals and habits of a group of people are transferred from one generation to another through the process of teaching, training or research. Education could take place in various schools and at different levels with the purpose of ensuring total development of the children. In Nigeria, there are several levels of education ranging from basic education, post-basic education and career development, mass and nomadic education, tertiary education, open and distance education and special needs education (FRN, 2014).

Tertiary education is the level of education that produces graduates from different fields of learning after four to seven years of study depending on the course of study. Tertiary education is the education given after post-basic education in institutions such as Universities and Inter-University Centres such as the Nigeria French Language Village, Nigeria Arabic Language Village, National Institute of Nigerian Languages, institutions such as Innovative Enterprise Institutions (IEIs) and Colleges of Education, Monotechnics, Polytechnics, Schools of Health and Technology and the National Teachers' Institutes (NTI) (FRN, 2014). Students admitted to study and obtain their first degrees in tertiary institutions are known as undergraduates.

The goals of tertiary education in Nigeria according to the national policy on education are to: contribute to national development through high level manpower training; provide accessible and affordable quality learning 
opportunities in formal and informal education in response to the needs and interests of all Nigerians; provide high quality career counseling and lifelong learning programmes that prepare students with the knowledge and skills for self-reliance and the world of work; reduce skill shortages through the production of skilled manpower relevant to the needs of the labour market; promote and encourage scholarship, entrepreneurship ant community service; forge and cement national unity; and promote national and international understanding and interaction (FRN, 2014). To achieve the goals of tertiary education, tertiary institutions were established with several apartments created to ensure the realization of the noble goals of the tertiary education. There is hardly any tertiary institution in Nigeria without the Department of Mathematics. This is basically because Mathematics education is indispensable to achieving the goals of tertiary education in Nigeria.

The national policy on education also specified that to achieve the goals of tertiary education which includes Mathematics education, the tertiary educational institutions shall pursue these goals through: quality student intake; quality teaching and learning, research and development; high standards in the quality of facilities, services and resources; staff welfare and development programmes; provision of a more practical based curriculum relevant to the needs of the labour market; access to training funds such as those provided by the Industrial Training Fund (ITF) and Tertiary Education Trust Fund (TETFund); well structured, coordinated and supervised Student Industrial Work Experience (SIWES); maintenance of minimum educational standards through appropriate regulatory agencies like the National University Commission (NUC), an all-inclusive credible admissions policy for national unity; supporting affordable, equitable access to tertiary education through scholarships and students' loans; inter-institutional cooperation and linkages; and dedicated services to the community through extra-mural and extension services (FRN, 2014).Notable factors from the policy provisions for effective instruction in tertiary institutions of learning are admission of qualified student and financial support through scholarship, quality teaching and learning by the lecturers through research, training and development and provision of high standard and quality educational facilities, services and resources by government, parents or individuals. Therefore, investigating the students, lecturers, parents, schools and government factors affecting undergraduate students' performance in Mathematics in Rivers State is the focus of this study.

Research report had revealed students' under-performance in Mathematics in tertiary institution. Wonu and Zalmon (2019) reported that most Mathematics students in tertiary institutions in Nigeria graduate with third class and second class honours (Lower division). It is therefore necessary to investigate the factors responsible for the poor achievement of students in Mathematics in Rivers State. There are seven public tertiary institutions in Rivers State but the study is interested in the three Universities awarding first degrees which are Ignatius Ajuru University of Education (IAUE), Rivers State University (RSU) and University of Port Harcourt (UNIPORT).The other tertiary institutions in the State are Elechi Amadi Polytechnic, Ken Saro-Wiwa Polytechnic, Federal College of Education (Technical) and Rivers State College of Health Science and Management Technology. However, the factors affecting undergraduate students' performance in Mathematics in Universities in Rivers State were investigated in this study.

\subsection{Statement of the Problem}

The need to study the factors which affect undergraduate students' performance in Mathematics is eminent following the public out-cry about the poor performance of undergraduate students in Mathematics. The researchers became so worried and questioned if the performance of undergraduate students in Mathematics could be traced to lecturers' competency, quality of instruction, parental factors, students' attitude towards learning Mathematics, poor teaching method, content difficulty, school and government factors. It is vital therefore to find out the factors which could be responsible for undergraduate student's performance in Mathematics by providing answer to the question: What are the factors affecting the performance of undergraduate students in Mathematics in Rivers State?

\subsection{Aim and Objectives of the Study}

The aim of this study was to investigate the factors affecting undergraduate students' performance in Mathematics in Rivers State. Specific objectives of the study were to:

- Determine the lecturer factors affecting the performance of undergraduate students in Mathematics in Rivers State.

- Find out the student factors that affect the performance of undergraduate students in Mathematics in Rivers State.

- Ascertain the parental factors affecting undergraduate student's performance in Mathematics in Rivers State.

- Find out the school factors affecting the performance of undergraduate students in Mathematics in Rivers State.

- Identify the governmental factors affecting undergraduate students' performance in Mathematics in Rivers State.

- Determine how these factors affect undergraduate students' performance in Mathematics.

\subsection{Research Questions}

- What are the lecturers' factors affecting the performance of undergraduate students in Mathematics in Rivers State?

- What are the students' factors affecting the performance of undergraduate students in Mathematics in Rivers State?

- What are the parental factors affecting undergraduate students' performance in Mathematics in Rivers State?

- What are the school factors affecting the performance of undergraduate students in Mathematics in Rivers State?

- What are the governmental factors affecting undergraduate students' performance in Mathematics in Rivers State?

- Determine the relationship between the factors and undergraduate students' performance in Mathematics? 


\subsection{Hypotheses}

- There is no significant relationship between lecturers' factors and undergraduate students' performance in Mathematics?

- There is no significant relationship between students' attitude and the performance of undergraduate students in Mathematics?

- There is no significant relationship between parental factors and undergraduate students' performance in Mathematics?

- There is no significant relationship between school factors and undergraduate students' performance in Mathematics?

- There is no significant relationship between governmental factors and undergraduate students' performance in Mathematics?

- There is no significant relationship between the factors and undergraduate students' performance in Mathematics?

\section{Methodology}

The study adopted the analytical survey design. An analytical survey concerns itself with ascertaining and establishing the status-quo, facts or pieces of information at the time of the research through the use of hypotheses and presenting such facts as they are. Analytical surveys are those studies which aim at collecting data and describing in a systematic manner, the characteristics features and facts about a given population by testing hypothesis. This study analyzed the factors affecting the performance of undergraduates in Mathematics for a sample of the population. The population of the study consisted of seven hundred and fifty-five (755) Level 100 to Level 400 undergraduate Mathematics students from the Department of Mathematics of the three Universities in Rivers State which are, University of Port Harcourt (UNIPORT), Rivers State University (RSU) and Ignatius Ajuru University of Education (IAUE) (Source: Department of Mathematics in the Universities, 2019).A sample of 249Mathematics undergraduates representing 33\% of the population as selected by stratified random sampling technique.

Two researcher developed instruments:

Factors Affecting Undergraduate Student Mathematics Performance Questionnaire (FAUSMPQ) and Algebra Performance Test (APT) were used for data collection. The FAUSMPQ contained section A and section B. Section A was used to seek information on the personal data of the respondents, while section B contained 70 items designed to elicit responses on the factors affecting undergraduate students' Mathematics performance. The FAUSMP Q was designed after the four-point Likert scale of Strongly Agree (SA) - 4 point, Agree (A) - 3 point, Disagree (D) - 2 point, Strongly Disagree (SD) - 1 point with a criterion mean of 2.50.The Algebra Performance Test (APT) which had sections A and B comprised of twenty (20) multiple-choice objective test items in level one hundred algebra course with four options used to determine the performance of undergraduate students in Mathematics. Each correct option scored 5 marks with zero mark for wrong option. The APT had a total of 100 score. The contents of the APT includes: indices and logarithms, polynomials, surds, quadratic equation theory, set theory and sequence.

The face and content validity of the FAUSMPQ and the APT were validated by two experts in Measurement and Evaluation and two experts in Mathematics education. All the observations made were effected before the distribution of the instrument. The reliability coefficients of FAUSMPQ and APT were established using test and retest method. The instruments were administered to twenty undergraduate students who were not part of the sample respondents. The instruments were re-administered after two weeks to the same respondents. The two sets of responses were correlated through Pearson's Product Moment Correlation (PPMC) for the two instruments and the reliability coefficients of 0.70 and 0.76 were obtained for FAUSMPQ and APT respectively. The FAUSMPQ and the APT were administered by the researchers directly to the students in the respective Departments of Mathematics of the Universities and retrieved immediately.

Data collected were analyzed using mean, standard deviation, Pearson's Product Moment Correlation (PPMC) and regression analysis. Mean and standard deviation were used to answer research questions one to five while PPMC was used to answer research question six. The six hypotheses were tested using regression analysis. The analysis was done using the Statistical Package for Social Sciences (SPSS) version 20.0.

\section{Results}

- Research question one: What are the lecturers' factors affecting the performance of undergraduate students in Mathematics in Rivers State? 


\begin{tabular}{|c|c|c|c|c|c|c|c|c|}
\hline $\mathbf{S} / \mathbf{N}$ & Lecturers Factors & SA & $\mathbf{A}$ & $\mathbf{D}$ & SD & Mean & $\begin{array}{l}\text { Std. } \\
\text { Dev. }\end{array}$ & Remark \\
\hline 1. & Poor teaching qualification & 129 & 31 & 28 & 61 & 2.92 & 1.27 & Agreed \\
\hline 2. & Ineffective teaching methods/ techniques & 39 & 110 & 59 & 41 & 2.59 & 0.94 & Agreed \\
\hline 3. & Negative lecturer-students relationship & 47 & 52 & 94 & 56 & 2.36 & 1.03 & Disagreed \\
\hline 4. & Ineffective teaching & 52 & 67 & 58 & 72 & 2.40 & 1.11 & Disagreed \\
\hline 5. & Lack of commitment of Mathematics lecturers & 59 & 69 & 60 & 61 & 2.51 & 1.10 & Agreed \\
\hline 6. & Lack of motivation on the side of the lecturers & 41 & 76 & 74 & 58 & 2.40 & 1.02 & Disagreed \\
\hline 7. & $\begin{array}{l}\text { Lecturers force students to apply their own } \\
\text { method of problem solving }\end{array}$ & 53 & 62 & 71 & 62 & 2.44 & 1.09 & Disagreed \\
\hline 8. & $\begin{array}{c}\text { Lecturers' negative attitude to student } \\
\text { understanding of concepts }\end{array}$ & 92 & 64 & 39 & 54 & 2.78 & 1.16 & Agreed \\
\hline 9. & $\begin{array}{l}\text { Lecturers' inability to cover the curriculum } \\
\text { contents during teaching }\end{array}$ & 42 & 84 & 70 & 53 & 2.46 & 1.01 & Disagreed \\
\hline 10. & $\begin{array}{l}\text { Lecturers' omitting or skipping teaching } \\
\text { certain topics of the curriculum perceived } \\
\text { difficult with them to teach }\end{array}$ & 63 & 51 & 74 & 61 & 2.35 & 1.05 & Disagreed \\
\hline 11. & $\begin{array}{c}\text { Lecturers don't cover the syllabus for the } \\
\text { term but set questions on the contents not } \\
\text { taught }\end{array}$ & 54 & 66 & 73 & 56 & 2.47 & 1.12 & Disagreed \\
\hline 12. & $\begin{array}{l}\text { Some lecturers don't solve mathematical } \\
\text { problems in the class }\end{array}$ & 45 & 77 & 72 & 55 & 2.47 & 1.07 & Disagreed \\
\hline 13. & Lecturers' lateness to class & 56 & 67 & 73 & 53 & 2.45 & 1.03 & Disagreed \\
\hline 14. & Lack of lesson preparation by lecturers & 58 & 67 & 61 & 63 & 2.51 & 1.06 & Agreed \\
\hline 15. & Lecturers teaching without lesson plan & 57 & 72 & 64 & 56 & 2.48 & 1.11 & Disagreed \\
\hline 16. & Lecturers set difficult questions in exam & 56 & 83 & 59 & 50 & 2.52 & 1.08 & Agreed \\
\hline 17. & Irregularity of some lecturers to classes & 60 & 68 & 67 & 54 & 2.58 & 1.05 & Agreed \\
\hline 18. & $\begin{array}{l}\text { Lecturers teaching Mathematics without } \\
\text { using instructional materials }\end{array}$ & 47 & 71 & 70 & 61 & 2.54 & 1.08 & Agreed \\
\hline 19. & $\begin{array}{l}\text { Poor classroom management by lecturers due } \\
\text { to large class }\end{array}$ & 43 & 50 & 72 & 84 & 2.42 & 1.06 & Disagreed \\
\hline 20. & Job mismatch & 129 & 31 & 28 & 61 & 2.21 & 1.09 & Disagreed \\
\hline & Grand Mean & & & & & 2.49 & 1.08 & Disagreed \\
\hline
\end{tabular}

Table 1: Mean Responses on Lecturers' Factors Affecting the Performance of Undergraduate Students in Mathematics

Data in table 1 indicated generally that the respondents disagreed that lecturers' factors affect the performance of undergraduate students in Mathematics ( $\mathrm{M}=2.49$; Std. Dev. $=1.08)$. However, data in table 1 also showed that respondents agreed that poor teaching qualification ( $M=2.92$; Std. Dev=1.27), lecturers' negative attitude to student understanding of concepts ( $\mathrm{M}=2.78$; Std. Dev/ =1.16), ineffective teaching methods and techniques ( $\mathrm{M}=2.59$; Std. Dev=0.94), irregularity of some lecturers to classes $(\mathrm{M}=2.58$; Std. Dev. $=1.05)$, lecturers teaching Mathematics without using instructional materials $(\mathrm{M}=2.54$; Std. Dev.=1.08), lecturers set difficult questions in exam $(\mathrm{M}=2.52$; Std. Dev.=1.08), lack of commitment of Mathematics lecturers ( $\mathrm{M}=2.51$; Std. Dev. $=1.10)$ and lack of lesson preparation by lecturers $(\mathrm{M}=2.51$; Std. Dev. $=1.06)$ were some of the lecturers' factors which affect the performance of undergraduate students in Mathematics.

- Research question two: What are the students' factors affecting the performance of undergraduate students in Mathematics in Rivers State?

\begin{tabular}{|l|c|c|c|c|c|c|c|c|}
\hline S/ N & Students Factors & SA & A & D & SD & Mean & $\begin{array}{c}\text { Std. } \\
\text { Dev. }\end{array}$ & Remark \\
\hline 21. & Lack of basic mathematical skills & 67 & 75 & 58 & 49 & 2.64 & 1.08 & Agreed \\
\hline 22. & Poor academic background of the students & 58 & 81 & 71 & 39 & 2.63 & 1.01 & Agreed \\
\hline 23. & Individual differences & 60 & 82 & 46 & 61 & 2.57 & 1.11 & Agreed \\
\hline 24. & $\begin{array}{c}\text { Students' lack of interest in studying } \\
\text { Mathematics }\end{array}$ & 63 & 79 & 62 & 45 & 2.64 & 1.05 & Agreed \\
\hline 25. & $\begin{array}{l}\text { Students negative attitude to learning } \\
\text { Mathematics }\end{array}$ & 65 & 77 & 55 & 52 & 2.62 & 1.09 & Agreed \\
\hline 26. & Psychological/ emotional problems & 62 & 90 & 52 & 45 & 2.68 & 1.04 & Agreed \\
\hline 27. & Lack of attention by students during teaching & 64 & 83 & 54 & 48 & 2.65 & 1.06 & Agreed \\
\hline 28. & Lack of collaboration in learning & 65 & 82 & 70 & 32 & 2.72 & 0.99 & Agreed \\
\hline 29. & Student absenteeism to Mathematics classes & 76 & 86 & 58 & 29 & 2.84 & 0.99 & Agreed \\
\hline 30. & Poor Mathematics study habit & 68 & 81 & 57 & 43 & 2.70 & 1.05 & Agreed \\
\hline 31. & Poor student-teacher relationship & 96 & 52 & 38 & 63 & 2.73 & 1.22 & Agreed \\
\hline 32. & Poor self-esteem among students & 50 & 99 & 73 & 27 & 2.69 & 0.91 & Agreed \\
\hline
\end{tabular}




\begin{tabular}{|l|c|c|c|c|c|c|c|c|}
\hline S/ N & Students Factors & SA & A & D & SD & Mean & $\begin{array}{c}\text { Std. } \\
\text { Dev. }\end{array}$ & Remark \\
\hline 33. & Examination malpractice over reliance & 49 & 109 & 62 & 29 & 2.71 & 0.91 & Agreed \\
\hline 34. & Involvement in emotional relationship & 74 & 86 & 47 & 42 & 2.77 & 1.05 & Agreed \\
\hline 35. & Excessive time spent on social media & 58 & 96 & 54 & 41 & 2.69 & 1.01 & Agreed \\
\hline 36. & $\begin{array}{c}\text { Failure to do some assignments given by the } \\
\text { lecturers }\end{array}$ & 59 & 94 & 63 & 33 & 2.72 & 0.97 & Agreed \\
\hline 37. & Mathematics phobia (fear) & 56 & 77 & 66 & 49 & 2.57 & 1.06 & Agreed \\
\hline 38. & Health challenge & 54 & 67 & 77 & 51 & 2.50 & 1.05 & Agreed \\
\hline 39. & Lack of hard work on the side of the students & 56 & 104 & 51 & 38 & 2.71 & 0.98 & Agreed \\
\hline & Grand Mean & & & & & 2.65 & 1.04 & Agreed \\
\hline
\end{tabular}

Table 2: Mean Responses on Students' Factors Affecting the Performance of Undergraduate Students in Mathematics

Data in table 2 indicated generally that the respondents agreed that students' factors affect the performance of undergraduates in Mathematics ( $\mathrm{M=2.65}$; Std. Dev.=1.04). Data in table 2 also revealed that some of the students' factors affecting their performance in Mathematics are student absenteeism to Mathematics classes $(\mathrm{M}=2.84$; Std. Dev. $=0.99)$, involvement in emotional relationship ( $\mathrm{M}=2.77$; Std. Dev. $=1.05)$, poor student-teacher relationship (interaction) $(\mathrm{M}=2.73$; Std. Dev.=1.22), lack of collaboration in learning $(\mathrm{M}=2.72$; Std. Dev. $=0.99)$, failure to do some assignments given by the lecturers ( $\mathrm{M}=2.72$; Std. Dev. $=0.97)$, examination malpractice over reliance $(\mathrm{M}=2.71$; Std. Dev. $=0.91)$, lack of hard work on the side of the students ( $M=2.71$; Std. Dev.=0.98),poor Mathematics study habit among students ( $M=2.70$; Std. Dev.=1.05), poor self-esteem among students ( $\mathrm{M}=2.69$; Std. Dev. $=0.91)$, excessive time spent on social media $(\mathrm{M}=2.69$; Std. Dev. $=1.01)$, psychological and emotional problems ( $\mathrm{M}=2.68$; Std. Dev.=1.04), lack of attention by students during teaching $(\mathrm{M}=2.65$; Std. Dev.=1.06), lack of basic mathematical skills $(M=2.64$; Std. Dev. $=1.08)$, lack of interest in studying Mathematics $(\mathrm{M}=2.64$; Std. Dev. $=1.05)$ and poor academic background of the students $(\mathrm{M}=2.63$; Std. Dev. $=1.01)$.

- Research question three: What are the parental factors affecting undergraduate students' performance in Mathematics in Rivers State?

\begin{tabular}{|l|c|c|c|c|c|c|c|c|}
\hline S/ N & Parental Factors & SA & A & D & SD & Mean & $\begin{array}{c}\text { Std. } \\
\text { Dev. }\end{array}$ & Remark \\
\hline 40. & Parental educational background & 64 & 93 & 50 & 42 & 2.72 & 1.03 & Agreed \\
\hline 41. & $\begin{array}{c}\text { Inadequate funding of education by parents in } \\
\text { providing necessary learning materials and } \\
\text { prompt payment of school fees }\end{array}$ & 70 & 75 & 58 & 46 & 2.68 & 1.07 & Agreed \\
\hline 42. & $\begin{array}{c}\text { Poor parental socio-economic status which } \\
\text { causes delay in school fees payment }\end{array}$ & 65 & 73 & 66 & 45 & 2.63 & 1.06 & Agreed \\
\hline 43. & $\begin{array}{c}\text { Lack of parental guidance and involvement in } \\
\text { their wards/ children academics }\end{array}$ & 60 & 95 & 65 & 29 & 2.75 & 0.95 & Agreed \\
\hline 44. & $\begin{array}{c}\text { Poor feeding habits of the learners due to } \\
\text { parent's insufficient finance }\end{array}$ & 40 & 94 & 65 & 50 & 2.50 & 0.99 & Agreed \\
\hline 45. & $\begin{array}{c}\text { Parental negligence in providing for their } \\
\text { children education }\end{array}$ & 46 & 106 & 57 & 40 & 2.63 & 0.96 & Agreed \\
\hline 46. & Lack of academic support from parents & 65 & 85 & 53 & 46 & 2.68 & 1.06 & Agreed \\
\hline & Grand Mean & & & & & 2.66 & 1.02 & Agreed \\
\hline
\end{tabular}

Table 3: Mean Responses on Parental Factors Affecting the Performance of Undergraduate Students in Mathematics

Data in table 3 indicated generally that the respondents agreed that parental factors affect the performance of undergraduate students in Mathematics ( $\mathrm{M}=2.66$; Std. Dev. $=1.02$ ). Data in table 3 also showed that some of the parental factors affecting students' performance in Mathematics are lack of parental guidance and involvement in their wards or children academics ( $\mathrm{M}=2.75$; Std. Dev.=0.95), parental educational background ( $\mathrm{M}=2.72$; Std. Dev. $=1.03$ ), inadequate funding of education by parents in providing necessary learning materials and prompt payment of school fees $(\mathrm{M}=2.68$; Std. Dev. $=1.07)$, lack of academic support from parents $(\mathrm{M}=2.68$; Std. Dev.=1.06), poor parental socio-economic status which causes delay in school fees payment $(\mathrm{M}=2.63$; Std. Dev.=1.06), parental negligence in providing for their children education $(\mathrm{M}=2.63$; Std. Dev. $=0.96)$ and poor feeding habits of the learners due to parents insufficient finance $(\mathrm{M}=2.50$; Std. Dev. $=0.99$ ).

- Research question four: What is the school factors affecting undergraduate students' performance in Mathematics in Rivers State? 


\begin{tabular}{|l|c|c|c|c|c|c|c|c|}
\hline S/ N & School Factors & SA & $\mathbf{A}$ & $\mathbf{D}$ & $\mathbf{S D}$ & Mean & $\begin{array}{c}\text { Std. } \\
\text { Dev. }\end{array}$ & Remark \\
\hline 47. & $\begin{array}{c}\text { Poor management of government libraries } \\
\text { and laboratories }\end{array}$ & 60 & 82 & 61 & 46 & 2.63 & 1.04 & Agreed \\
\hline 48. & $\begin{array}{c}\text { Excessive workload given to the students by } \\
\text { the school management }\end{array}$ & 58 & 93 & 58 & 40 & 2.68 & 1.00 & Agreed \\
\hline 49. & Overcrowding of the teaching time table & 98 & 63 & 57 & 31 & 2.92 & 1.06 & Agreed \\
\hline 50. & Poor study and learning environment & 58 & 102 & 50 & 39 & 2.72 & 0.99 & Agreed \\
\hline 51. & $\begin{array}{c}\text { Impatience in examination supervision by the } \\
\text { examiners }\end{array}$ & 73 & 81 & 59 & 36 & 2.77 & 1.03 & Agreed \\
\hline 52. & Overcrowding of the examination time table & 50 & 101 & 62 & 36 & 2.66 & 0.96 & Agreed \\
\hline 53. & $\begin{array}{c}\text { Too many courses to offer in the school } \\
\text { curriculum }\end{array}$ & 67 & 89 & 56 & 37 & 2.75 & 1.01 & Agreed \\
\hline 54. & $\begin{array}{c}\text { Poor orientation by the school on gaining } \\
\text { admission }\end{array}$ & 56 & 102 & 55 & 36 & 2.71 & 0.97 & Agreed \\
\hline 55. & $\begin{array}{c}\text { Excessive financial demands on parents by } \\
\text { the school management }\end{array}$ & 57 & 95 & 57 & 40 & 2.68 & 1.00 & Agreed \\
\hline 56. & $\begin{array}{c}\text { Lack of student accommodation for boarding } \\
\text { system. }\end{array}$ & 55 & 72 & 68 & 54 & 2.51 & 1.06 & Agreed \\
\hline 57. & $\begin{array}{c}\text { Poor management of government libraries } \\
\text { and laboratories }\end{array}$ & 56 & 90 & 61 & 42 & 2.64 & 1.01 & Agreed \\
\hline 58. & $\begin{array}{c}\text { Excessive workload given to students by the } \\
\text { school management }\end{array}$ & 58 & 84 & 62 & 45 & 2.62 & 1.03 & Agreed \\
\hline & Grand Mean & & & & & 2.69 & 1.01 & Agreed \\
\hline
\end{tabular}

Table 4: Mean Responses on School Factors Affecting the Performance of Undergraduate Students in Mathematics

Data in table 4 indicated generally that the respondents agreed that school factors affect the performance of undergraduate students in Mathematics ( $\mathrm{M}=2.69$; Std. Dev.=1.01). Data in table 4 also revealed that some of the school factors affecting undergraduate students' performance in Mathematics are overcrowding of the teaching time table $(\mathrm{M}=2.92$; Std. Dev. $=1.06)$, impatience in examination supervision by examiners $(\mathrm{M}=2.77$; Std. Dev. $=1.03)$, too many courses to offer in the school curriculum ( $\mathrm{M}=2.75$; Std. Dev.=1.01), poor study and learning environment ( $\mathrm{M}=2.72$; Std. Dev.=0.99), poor orientation by the school on gaining admission $(\mathrm{M}=2.71$; Std. Dev.. Dev. $=0.97)$, excessive workload given to the students by the school management $(\mathrm{M}=2.68$; Std. Dev.=1.00), excessive financial demands on parents by the school management $(\mathrm{M}=2.68$; Std. Dev. $=1.00)$, overcrowding of the examination time table $(\mathrm{M}=2.66$; Std. Dev. $=0.96)$ and poor management of government libraries and laboratories ( $\mathrm{M}=2.64$; Std. Dev.=1.01).

- Research question five: What are the governmental factors affecting the performance of undergraduate students in Mathematics in Rivers State?

\begin{tabular}{|l|c|c|c|c|c|c|c|c|}
\hline S/ N & Government Factors & SA & A & D & SD & Mean & $\begin{array}{c}\text { Std. } \\
\text { Dev. }\end{array}$ & Remark \\
\hline 59. & Lack of classrooms & 51 & 100 & 53 & 45 & 2.63 & 1.00 & Agreed \\
\hline 60. & Lack of instructional materials & 67 & 83 & 56 & 43 & 2.70 & 1.05 & Agreed \\
\hline 61. & $\begin{array}{c}\text { Inadequate employment of qualified } \\
\text { Mathematics lecturers }\end{array}$ & 68 & 99 & 66 & 16 & 2.88 & 0.89 & Agreed \\
\hline 62. & Policy issues encouraging large class size & 47 & 57 & 72 & 73 & 2.31 & 1.09 & Disagreed \\
\hline 63. & Lack of infrastructures & 63 & 75 & 69 & 42 & 2.64 & 1.04 & Agreed \\
\hline 64. & Lack of offices for lecturers & 54 & 74 & 69 & 52 & 2.52 & 1.05 & Agreed \\
\hline 65. & Lack of Mathematics laboratory & 56 & 91 & 64 & 38 & 2.66 & 0.99 & Agreed \\
\hline 66. & Poor payment of salary & 54 & 82 & 57 & 56 & 2.54 & 1.07 & Agreed \\
\hline 67. & $\begin{array}{c}\text { Poor supervision, monitoring and } \\
\text { management of public schools }\end{array}$ & 63 & 81 & 59 & 46 & 2.65 & 1.05 & Agreed \\
\hline 68. & Dilapidated structures/ buildings & 60 & 91 & 58 & 40 & 2.69 & 1.01 & Agreed \\
\hline 69. & $\begin{array}{c}\text { Absence of learning materials like chalk, } \\
\text { marker, white board, dusters, pen, chalk } \\
\text { board, desk, etc. }\end{array}$ & 68 & 88 & 53 & 40 & 2.74 & 1.03 & Agreed \\
\hline 70. & $\begin{array}{c}\text { Undue interference on academic calendars by } \\
\text { government }\end{array}$ & 57 & 89 & 59 & 44 & 2.64 & 1.02 & Agreed \\
\hline & Grand Mean & & & & & 2.63 & 1.02 & Agreed \\
\hline
\end{tabular}

Table 5: Mean Responses on Governmental Factors Affecting the Performance of Undergraduate Students in Mathematics

Data in table 5 indicated generally that the respondents agreed that government factors affect the performance of undergraduate students in Mathematics $(M=2.63$; Std. Dev. $=1.02)$. Data in table 5 also revealed that some of the governmental factors affecting undergraduate students' performance in Mathematics are inadequate employment of 
qualified Mathematics lecturers ( $M=2.88$; Std. Dev.=0.89), absence of learning materials ( $M=2.74$; Std. Dev.=1.03), lack of instructional materials ( $M=2.70$; Std. Dev. $=1.05)$, dilapidated structures or buildings ( $M=2.69$; Std. Dev. $=1.01)$, lack of Mathematics laboratory ( $\mathrm{M}=2.66$; Std. Dev. $=0.99$ ), poor supervision, monitoring and management of public schools $(\mathrm{M}=2.65$; Std. Dev.=1.05), lack of infrastructures $(\mathrm{M}=2.64 ; \mathrm{Std}=1.04)$, undue interference on academic calendar by government ( $\mathrm{M=2.64}$; Std. Dev.=1.02) and lack of classrooms ( $\mathrm{M}=2.63$; Std. Dev.=1.00).

- Research question six: What is the relationship between the factors and undergraduate students' performancein Mathematics?

\begin{tabular}{|c|c|c|c|c|}
\hline Model & R & R Square & $\begin{array}{c}\text { Adjusted R } \\
\text { Square }\end{array}$ & $\begin{array}{c}\text { Std. Error of the } \\
\text { Estimate }\end{array}$ \\
\hline 1 & $.14^{\mathrm{a}}$ & .019 & .015 & 13.38120 \\
\hline
\end{tabular}

Table 6: Summary of Pearson's Product Moment Correlation on the Relationship between the Factors and Undergraduate Students' Performance in Mathematics

a. Predictors: (Constant), Factors

Data intable 6 showed that there is a positive relationship between the lecturer, student, parent, government and school factors and undergraduate students' performance in Mathematics $(r=0.14)$.Data in table 6 also revealed that the factors account for only 1.9\% (.019x100) effect on undergraduate students' performance in Mathematics, which implies that the remaining $98.1 \%$ of undergraduate students' performance in Mathematics is explained by factors outside the model.

- Ho1: There is no significant relationship between lecturers' factors and undergraduate students' performance in Mathematics.

\begin{tabular}{|c|c|c|c|c|c|c|c|c|c|c|}
\hline & & & A. Mod & Summ & & & & & & \\
\hline & del & $\mathrm{R}$ & R Square & $\begin{array}{r}\text { Adj } \\
\text { Sc }\end{array}$ & $\begin{array}{l}\text { ted R } \\
\text { are }\end{array}$ & $\begin{array}{r}\text { Std. Er } \\
\text { Est }\end{array}$ & $\begin{array}{l}\text { of of the } \\
\text { nate }\end{array}$ & & & \\
\hline & 1 & $.13^{a}$ & .017 & & 13 & 13. & 9540 & & & \\
\hline & & a. Predi & tors: (Con & int), Le & turer $\mathrm{F}$ & & & & & \\
\hline & & & & & ANOI & & & & & \\
\hline & & odel & Sum of Sc & ares & Df & Mean S & uare & $\mathrm{F}$ & Sig. & \\
\hline & & Regression & 778.5 & & 1 & 778. & & 4.339 & $.038^{b}$ & \\
\hline & & Residual & 44320. & & 247 & 179. & & & & \\
\hline & & Total & 45099. & & 248 & & & & & \\
\hline & & & a. Depe & ent Va & able: $P$ & formanc & Score & & & \\
\hline & & & b. Pred & tors: (C & nstant) & Lecturer & actor & & & \\
\hline & & & & & C. $\mathrm{C}$ & fficients & & & & \\
\hline & & odel & $\begin{array}{l}\text { Unstand } \\
\text { Coeffic }\end{array}$ & $\begin{array}{l}\text { dized } \\
\text { nts }\end{array}$ & $\begin{array}{r}\text { Stan } \\
\text { Coe } \\
\end{array}$ & \begin{tabular}{|l|} 
Irdized \\
cients
\end{tabular} & $\mathrm{t}$ & Sig. & $\begin{array}{r}95.0 \% \\
\text { Inter } \\
\end{array}$ & $\begin{array}{l}\text { idence } \\
\text { or B }\end{array}$ \\
\hline & & & B & $\begin{array}{l}\text { Std. } \\
\text { Error }\end{array}$ & & ta & & & $\begin{array}{l}\text { Lower } \\
\text { Bound }\end{array}$ & $\begin{array}{l}\text { Upper } \\
\text { Bound }\end{array}$ \\
\hline 1 & & onstant) & 56.288 & 3.473 & & & 16.207 & .000 & 49.447 & 63.129 \\
\hline & & urerFactor & -.141 & .068 & & 31 & -2.083 & .038 & -.274 & -.008 \\
\hline
\end{tabular}

Table 7: Summary of Regression on the Relationship between Lecturers'

Factors and Undergraduate Students' Performance in Mathematics

Data in table 7 showed that there is a significant positive relationship between lecturers' factors and undergraduate students' performance in Mathematics $\left(\mathrm{F}_{(1,247)}=4.339, \mathrm{p} \varangle 0.05 ; \mathrm{r}=0.13\right)$. Therefore, the null hypothesis one was rejected and the alternate hypothesis retained. Data in table 7 also revealed that the lecturers' factors affect the undergraduate students' Mathematics performance by $1.7 \%(0.017 \times 100)$ indicating that the remaining $98.3 \%$ of undergraduate students' performance is explained by other variables not included in the model. The regression equation $y=56.288-0.141 x$ indicated that a unit increase in lecturer factors will lead to a unit decrease in undergraduate students' performance in Mathematics by 0.141 .

- $\mathrm{H}_{02}$ : There is no significant relationship between student attitude and the performance of undergraduate students in Mathematics. 


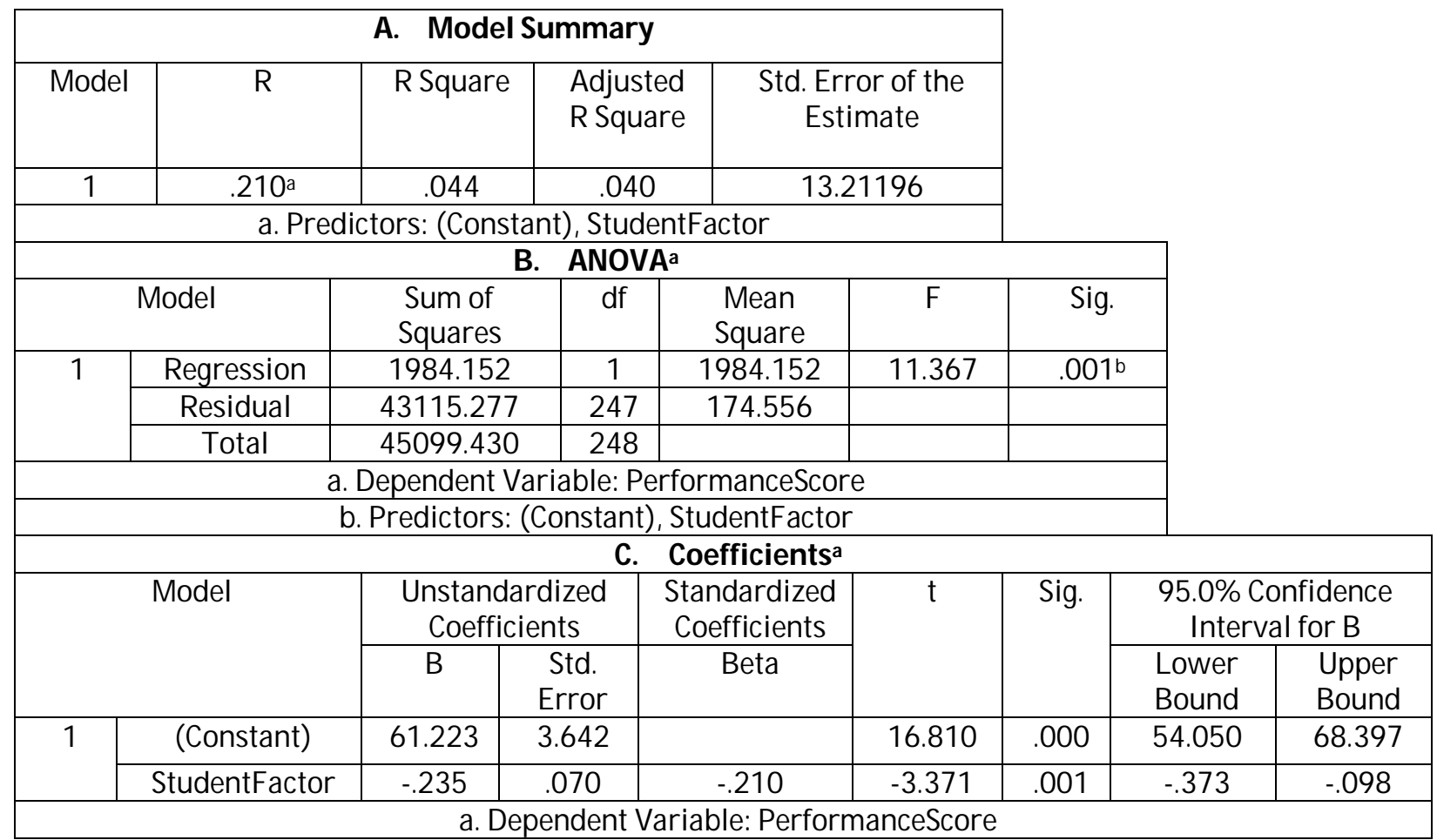

Table 8: Summary of Regression on the Relationship between Students

Factors and Undergraduate Students' Performance in Mathematics

Data in table 8 showed that there is a significant positive relationship between students' factors and their performance in Mathematics $\left(F_{(1,247)}=11.367, p \varangle 0.05 ; r=0.21\right)$. Therefore, the null hypothesis two was rejected and the alternate hypothesis retained. Data in table 8 also revealed that the students' factors affect their Mathematics performance by $4.4 \%(0.044 \times 100)$ indicating that the remaining $95.6 \%$ of undergraduate students' performance is explained by other variables not included in the model. The regression equation $y=61.223-0.235 x$ indicated that a unit increase in student factors will lead to a unit decrease in undergraduate students' performance in Mathematics by 0.235 .

- $\mathrm{H}_{03}$ : There is no significant relationship between parental factors and undergraduate students' performance in Mathematics.

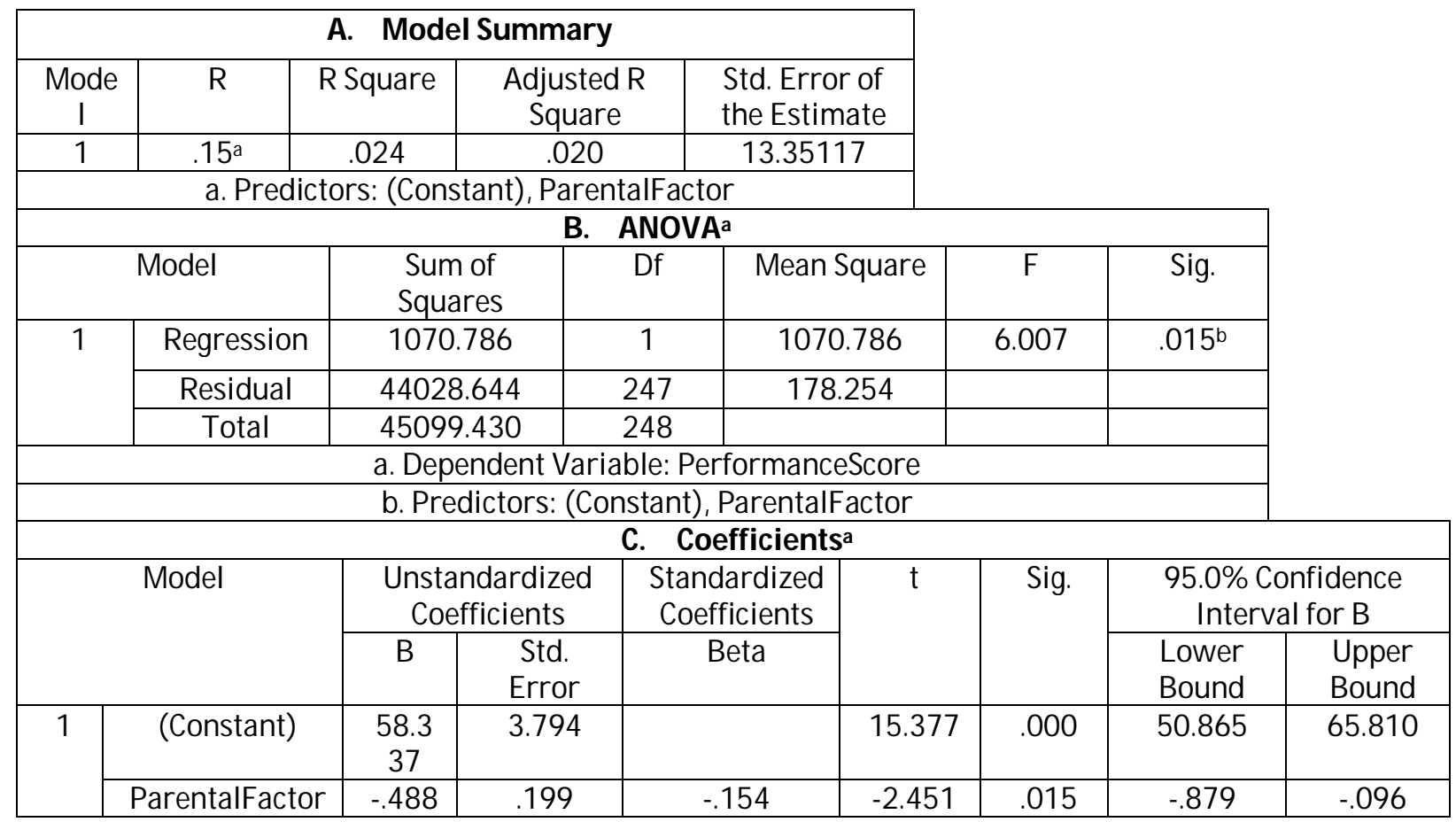

Table 9: Summary of Regression on the Relationship between Parental Factors and Undergraduate Students' Performance in Mathematics a. Dependent Variable: Performance Score

Data in table 9 showed that there is a significant positive relationship between parental factors and undergraduate student performance in Mathematics $\left(\mathrm{F}_{(1,247)}=6.007, \mathrm{p} \varangle 0.05 ; \mathrm{r}=0.15\right)$. Therefore, the null hypothesis 
three was rejected and the alternate hypothesis retained. Data in table 9 also revealed that the parental factors affect undergraduate students' Mathematics performance by $2.4 \%(0.024 \times 100)$ indicating that the remaining $97.6 \%$ of undergraduate students' performance is explained by other variables not included in the model. The regression equation $y=58.337-0.488 x$ indicated that a unit increase in parental factors will lead to a unit decrease in undergraduate students' performance in Mathematics by 0.488 .

- $\mathrm{H}_{04}$ : There is no significant relationship between school factors and undergraduate students' performance in Mathematics.

\begin{tabular}{|c|c|c|c|c|c|c|c|c|c|}
\hline \multicolumn{7}{|c|}{ A. Model Summary } & & & \\
\hline Model & $\mathrm{R}$ & R Square & \multirow{2}{*}{\multicolumn{2}{|c|}{$\begin{array}{c}\text { Adjusted R } \\
\text { Square }\end{array}$}} & \multirow{2}{*}{\multicolumn{2}{|c|}{$\begin{array}{l}\text { Std. Error of the } \\
\text { Estimate }\end{array}$}} & & & \\
\hline & & & & & & & & & \\
\hline 1 & .08 & .006 & \multicolumn{2}{|c|}{.002} & \multicolumn{2}{|c|}{13.47339} & & & \\
\hline \multirow{2}{*}{\multicolumn{9}{|c|}{$\begin{array}{l}\text { a. Predictors: (Constant), School Factor } \\
\text { B. ANOVA }\end{array}$}} & \\
\hline & & & & & & & & & \\
\hline \multicolumn{2}{|r|}{ Model } & $\begin{array}{l}\text { Sum of } \\
\text { Squares }\end{array}$ & Df & & Mean Square & \multicolumn{2}{|l|}{$\mathrm{F}$} & Sig. & \\
\hline \multirow[t]{3}{*}{1} & Regression & 260.993 & \multirow{2}{*}{$\frac{1}{247}$} & & 260.993 & \multirow[t]{2}{*}{1.438} & & $.232^{\mathrm{b}}$ & \\
\hline & Residual & 44838.437 & & \multicolumn{2}{|r|}{181.532} & & & 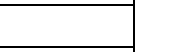 & \\
\hline & Total & 45099.430 & \begin{tabular}{l|l}
248 \\
\end{tabular} & & & & & & \\
\hline \multicolumn{9}{|c|}{ a. Dependent Variable: Performance Score } & \\
\hline \multicolumn{9}{|c|}{ b. Predictors: (Constant), School Factors } & \\
\hline \multicolumn{10}{|c|}{$\begin{array}{r}\text { C. } \text { Coefficients }^{\mathbf{a}} \\
\end{array}$} \\
\hline \multirow{2}{*}{\multicolumn{2}{|c|}{ Model }} & \multicolumn{2}{|c|}{$\begin{array}{l}\text { Unstandardized } \\
\text { Coefficients }\end{array}$} & $\begin{array}{r}\text { Stan } \\
\text { Coe }\end{array}$ & $\begin{array}{l}\text { dardized } \\
\text { fficients }\end{array}$ & \multirow[t]{2}{*}{$\mathrm{t}$} & \multirow[t]{2}{*}{ Sig. } & \multicolumn{2}{|c|}{$\begin{array}{c}\text { 95.0\% Confidence } \\
\text { Interval for B }\end{array}$} \\
\hline & & B & $\begin{array}{c}\text { Std. } \\
\text { Error }\end{array}$ & & Beta & & & $\begin{array}{l}\text { Lower } \\
\text { Bound }\end{array}$ & $\begin{array}{l}\text { Upper } \\
\text { Bound }\end{array}$ \\
\hline \multirow[t]{2}{*}{1} & (Constant) & 44.822 & 3.809 & & & $\begin{array}{c}11.76 \\
7\end{array}$ & .000 & 37.320 & 52.324 \\
\hline & School Factors & -.141 & .117 & & .076 & 1.199 & .232 & -.091 & .372 \\
\hline
\end{tabular}

Table 10: Summary Of Regression On The Relationship Between School Factors And Undergraduate Students' Performancein Mathematics

Data in table 10 showed that there is an insignificant positive relationship between school factors and undergraduate student performance in Mathematics $\left(\mathrm{F}_{(1,247)}=1.438, \mathrm{p}>0.05 ; \mathrm{r}=0.08\right)$. Therefore, the null hypothesis four was retained and the alternate hypothesis rejected. Data in table 10 also revealed that the school factors affect undergraduate students' Mathematics performance by $0.6 \%(0.006 \times 100)$ indicating that the remaining $99.4 \%$ of undergraduate students' performance is explained by other variables not included in the model. The regression equation $y=44.822-0.141 x$ indicated that a unit increase in school factors will lead to a unit decrease in undergraduate students performance in Mathematics by 0.141 .

- $\mathrm{H}_{05}$ : There is no significant relationship between governmental factors and undergraduate students' performance in Mathematics? 


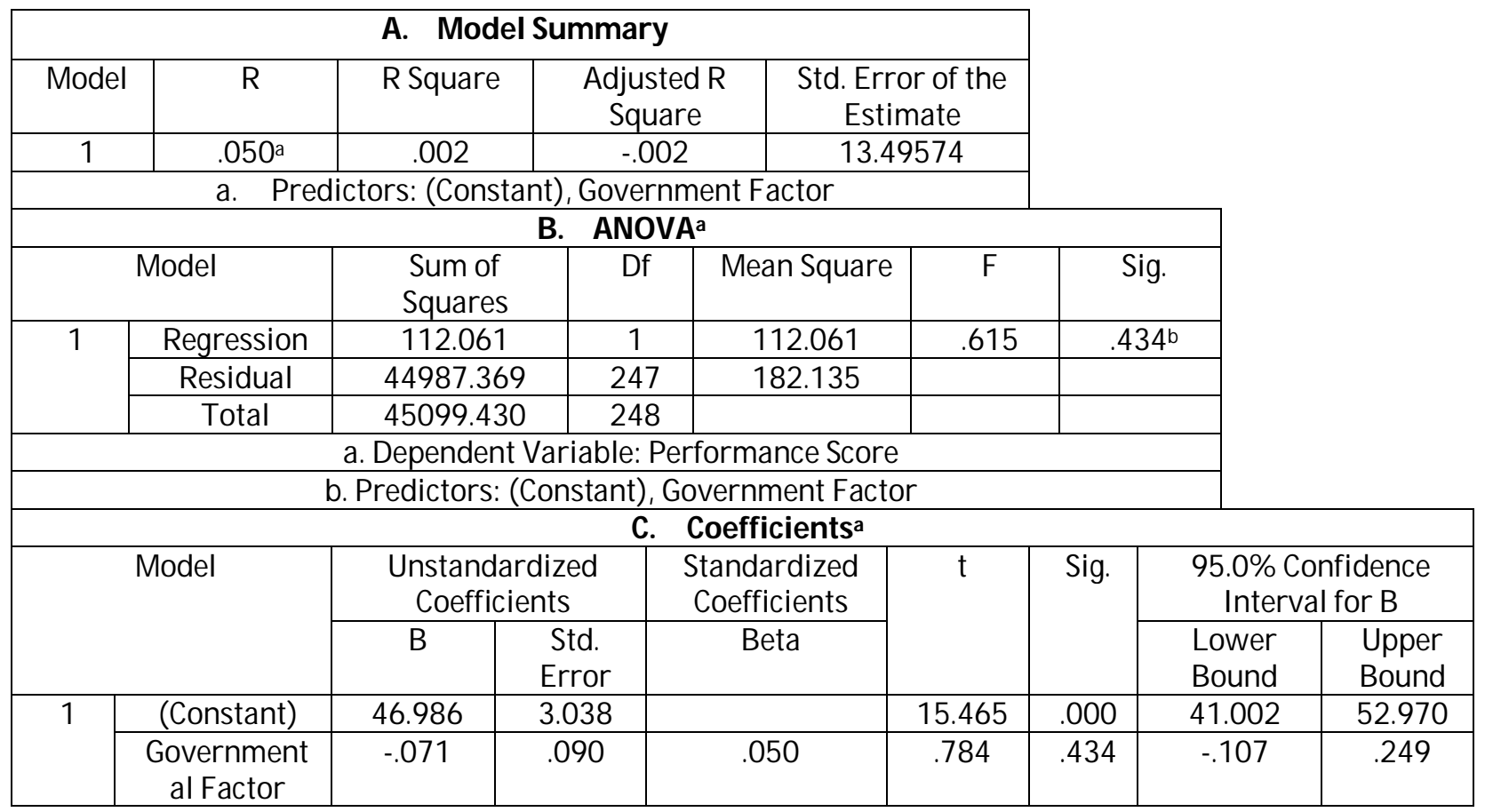

Table 11: Summary of Regression on the Relationship between Governmental Factors and Undergraduate Students' Performance in Mathematics

a. Dependent Variable: Performance Score

Data in table 11 showed that there is an insignificant positive relationship between governmental factors and undergraduate student performance in Mathematics $\left(F_{(1,247)}=0.615, p>0.05 ; r=0.05\right)$. Therefore, the null hypothesis five was retained and the alternate hypothesis rejected. Data in table 11 also revealed that governmental factors affect undergraduate students' Mathematics performance by $0.2 \%(0.002 \times 100)$ indicating that the remaining $99.8 \%$ of undergraduate students' performance is explained by other variables not included in the model. The regression equation $y=46.986-0.071 x$ indicated that a unit increase in governmental factors will lead to a unit decrease in undergraduate students' performance in Mathematics by 0.071 .

- $\mathrm{H}_{06}$ : There is no significant relationship between the factors and undergraduate students' performancein Mathematics?

\begin{tabular}{|c|c|c|c|c|c|c|c|c|c|c|}
\hline \multicolumn{9}{|c|}{ A. Model Summary } & & \\
\hline Model & \multicolumn{2}{|l|}{$\mathrm{R}$} & \multicolumn{2}{|c|}{ R Square } & \multicolumn{2}{|c|}{$\begin{array}{l}\text { Adjusted R } \\
\text { Square }\end{array}$} & \multicolumn{2}{|c|}{$\begin{array}{l}\text { Std. Error of } \\
\text { the Estimate }\end{array}$} & & \\
\hline & $.14^{\circ}$ & \multicolumn{3}{|c|}{.019} & \multicolumn{2}{|l|}{.015} & \multicolumn{2}{|c|}{13.38120} & & \\
\hline \multicolumn{9}{|c|}{ a. Predictors: (Constant), Factors } & & \\
\hline \multicolumn{9}{|c|}{ B. ANOVA $^{\mathrm{a}}$} & & \\
\hline \multicolumn{2}{|r|}{ Model } & $\begin{array}{l}\text { Sum c } \\
\text { Squar }\end{array}$ & & $\mathrm{df}$ & $\begin{array}{c}\text { Mean } \\
\text { Square }\end{array}$ & & $\mathrm{F}$ & Sig. & & \\
\hline \multirow[t]{3}{*}{1} & Regression & \multicolumn{2}{|c|}{872.454} & 1 & 872.454 & & 873 & & & \\
\hline & Residual & \multicolumn{2}{|c|}{44226.975} & 247 & 179.057 & & & $.028^{\mathrm{b}}$ & & \\
\hline & Total & \multicolumn{2}{|c|}{45099.430} & 248 & & & & \multirow{2}{*}{ 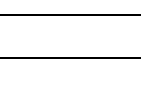 } & & \\
\hline \multirow{2}{*}{\multicolumn{8}{|c|}{ a. Dependent Variable: Performance Score }} & & & \\
\hline \multicolumn{6}{|c|}{ b. Predictors: (Constant), Factors } & & & & & \\
\hline \multicolumn{11}{|c|}{$\begin{array}{l}\text { C. } \text { Coefficients }^{\mathrm{a}} \\
\end{array}$} \\
\hline \multirow{2}{*}{\multicolumn{2}{|c|}{ Model }} & \multicolumn{3}{|c|}{$\begin{array}{c}\text { Unstandardized } \\
\text { Coefficients }\end{array}$} & \multicolumn{2}{|c|}{$\begin{array}{c}\text { Standardized } \\
\text { Coefficients }\end{array}$} & \multirow[t]{2}{*}{$\mathrm{T}$} & \multirow[t]{2}{*}{ Sig. } & \multicolumn{2}{|c|}{$\begin{array}{l}\text { 95.0\% Confidence } \\
\text { Interval for B }\end{array}$} \\
\hline & & $\mathrm{B}$ & & $\begin{array}{l}\text { td. } \\
\text { ror }\end{array}$ & Beta & & & & $\begin{array}{l}\text { Lower } \\
\text { Bound }\end{array}$ & $\begin{array}{l}\text { Upper } \\
\text { Bound }\end{array}$ \\
\hline 1 & (Constant) & 61.827 & & 750 & & & 10.7 & .000 & 50.501 & 73.153 \\
\hline & Factors & -.069 & & 31 & -.139 & & -2.2 & .028 & -.130 & -.007 \\
\hline
\end{tabular}

Table 12: Summary of Regression on the Relationship between the Factors and Undergraduate Students' Performance In Mathematics Dependent Variable: Performance Score

Data in table 12 showed that there is a significant positive relationship between the lecturer, student, parent, government and school factors and undergraduate students' performance in Mathematics $\left(\mathrm{F}_{(1,247)}=4.873, \mathrm{p} \varangle 0.05 ; \mathrm{r}=\right.$ 0.14). Therefore, the null hypothesis six was rejected and the alternate hypothesis retained. Data in table 12 also revealed 
that all the factors affect undergraduate students' Mathematics performance by $1.9 \%(0.019 \times 100)$ indicating that the remaining $98.1 \%$ of undergraduate students' performance is explained by other variables not included in the model. The regression equation $y=61.827-0.069 x$ indicated that a unit increase in the factors will lead to a unit decrease in undergraduate students' performance in Mathematics by 0.069 .

\section{Discussion of Findings}

\subsection{Lecturers' Factors Affecting the Performance of Undergraduate Students in Mathematics}

Data in table 1 indicated generally that the respondents disagreed that lecturers' factors affect the performance of undergraduate students in Mathematics ( $\mathrm{M}=2.49$; Std. Dev. $=1.08$ ). However, data in table 1 also showed that respondents agreed that poor teaching qualification ( $\mathrm{M}=2.92$; Std. Dev. $=1.27)$, lecturers' negative attitude to student understanding of concepts (M=2.78; Std. Dev.=1.16), ineffective teaching methods and techniques ( $M=2.59$; Std. Dev.=0.94), irregularity of some lecturers to classes $(\mathrm{M}=2.58$; Std. Dev. $=1.05)$, lecturers teaching Mathematics without using instructional materials $(\mathrm{M}=2.54$; Std. Dev. $=1.08)$, lecturers set difficult questions in exam $(\mathrm{M}=2.52$; Std. Dev=1.08), lack of commitment of Mathematics lecturers ( $\mathrm{M}=2.51$; Std. $\mathrm{Dev}=1.10)$ and lack of lesson preparation by lecturers $(\mathrm{M}=2.51$; Std. Dev $=1.06)$ were some of the lecturers' factors affecting the performance of undergraduate students in Mathematics. Data in table 7 showed that there is a significant positive relationship between lecturers' factors and undergraduate students' performance in Mathematics $\left(F_{(1,247)}=4.339, \mathrm{p}<0.05 ; \mathrm{r}=0.13\right)$. Data in table 7 also revealed that the lecturers' factors affect the undergraduate students' Mathematics performance by $1.7 \%$.

Nyadanu, Garglo, Adampah and Garglo (2014) identified lecturer-student relationships as a drive of self-esteem of students for higher academic performance. Okello (2014) established that the lecturer-student relationship during College Algebra classroom lessons can create either a positive or negative impact on the students learning process and hence the overall performance in College algebra examinations'. Xian and Wilkins (2015) found out that lecturer commitment to students' academic performance and lecturer commitment to the social integration of students are both positively related to student satisfaction.Waseka, Enose, Simatwa and Okwach (2016) established that teacher factors influenced students' academic performance by 59.4\%. This high effect of teacher factor on students' academic performance in this report was because the study was conducted in secondary schools and not tertiary institution.Olatunji, Aghimien, Emmanuel and Olushola (2016) revealed that parents and lecturers have the highest influence on the success of undergraduate students in construction related disciplines in Nigerian while school board members have the lesser impact. Concentration, lack of reading habit and class size are the major identified factors affecting the performance of undergraduates. The study therefore recommended that parents and lecturers should be made aware of their roles in the success of their wards while necessary facilities in term of accommodation and serene environment on campus should be provided for students as this will enhance students' concentration, hence increasing the rate of students' success.

\subsection{Student Factors Affecting the Performance of Undergraduate Students in Mathematics}

Data in table 2 indicated generally that the respondents agreed that students' factors affect the performance of undergraduates in Mathematics ( $M=2.65$; Std. Dev. $=1.04)$. Data in table 2 also revealed that some of the students' factors affecting their performance in Mathematics are student absenteeism to Mathematics classes ( $\mathrm{M}=2.84$; Std. Dev.=0.99), involvement in emotional relationship ( $\mathrm{M}=2.77$; Std. Dev=1.05), poor student-teacher relationship (interaction) $(\mathrm{M}=2.73$; $\mathrm{Std}=1.22)$, lack of collaboration in learning $(\mathrm{M}=2.72$; $\mathrm{Std}=0.99)$, failure to do some assignments given by the lecturers $(\mathrm{M}=2.72$; Std. Dev. $=0.97)$, examination malpractice over reliance $(\mathrm{M}=2.71$; Std. Dev. $=0.91)$, lack of hard work on the side of the students ( $M=2.71$; Std. Dev=0.98), poor Mathematics study habit among students ( $M=2.70$; Std. $D e v=1.05)$, poor selfesteem among students $(\mathrm{M}=2.69$; Std. Dev. $=0.91)$, excessive time spent on social media $(\mathrm{M}=2.69$; Std. Dev=1.01), psychological and emotional problems $(\mathrm{M}=2.68$; Std. Dev.=1.04), lack of attention by students during teaching $(\mathrm{M}=2.65$; $\mathrm{Std}=1.06)$, lack of basic mathematical skills $(\mathrm{M}=2.64$; Std. Dev.=1.08), lack of interest in studying Mathematics ( $\mathrm{M}=2.64$; Std. Dev. $=1.05)$ and poor academic background of the students $(M=2.63$; Std. Dev.=1.01). Data in table 8 showed that there is a significant positive relationship between students' factors and their performance in Mathematics $\left(\mathrm{F}_{(1,247)}=11.367\right.$, $\mathrm{p}<0.05 ; \mathrm{r}=0.21$ ). Data in table 8 also revealed that the students' factors affect their Mathematics performanceby $4.4 \%$.

Olatunji, Aghimien, Emmanuel and Olushola (2016) revealed that parents and lecturers have the highest influence on the success of undergraduate students in construction related disciplines in Nigerian while school board members have the lesser impact. Concentration, lack of good reading habit and class size are the major identified factors affecting the performance of undergraduates. The study therefore recommended that parents and lecturers should be made aware of their roles in the success of their wards while necessary facilities in term of accommodation and serene environment on campus should be provided for students as this will enhance students' concentration, hence increasing the rate of students' success. Mphale and Mhalauli (2014) showed that there were several factors that can contribute toward students' low academic performance ranging from low staff morale to student's unpreparedness for the examinations. Harb and El-Shaarawi (2006) reported that hard work, previous schooling, parents' education, family income and selfmotivation are factors that have a significant effect on the students Grade Point Average (GPA). Anderson (2015)opined that better attitude towards Mathematics is associated with higher mark in performance testsand determines the students' performance level.

\subsection{Parental Factors Affecting Undergraduate Students' Performance in Mathematics}

Data in table 3 indicated generally that the respondents agreed that parental factors affect the performance of undergraduate students in Mathematics ( $M=2.66$; Std. Dev.=1.02). Data in table 3 also showed that some of the parental 
factors affecting students' performance in Mathematics are lack of parental guidance and involvement in their wards or children academics $(M=2.75$; $S t d=0.95)$, parental educational background $(M=2.72$; $S t d=1.03)$, inadequate funding of education by parents in providing necessary learning materials and prompt payment of school fees ( $\mathrm{M}=2.68$; Std=1.07), lack of academic support from parents $(\mathrm{M}=2.68$; Std. Dev.=1.06), poor parental socio-economic status which causes delay in school fees payment $(\mathrm{M}=2.63$; Std. Dev.=1.06), parental negligence in providing for their children education $(\mathrm{M}=2.63$; Std. Dev. $=0.96)$ and poor feeding habits of the learners due to parents insufficient finance ( $M=2.50$; Std. Dev. =0.99). Data in table 9 showed that there is a significant positive relationship between parental factors and undergraduate student performance in Mathematics $\left(\mathrm{F}_{(1,247)}=6.007, \mathrm{p} \varangle 0.05 ; \mathrm{r}=0.15\right)$. Data in table 9 also revealed that the parental factors affect undergraduate students' Mathematics performance by $2.4 \%$.

Olatunji, Aghimien, Emmanuel and Olushola (2016) revealed that parents and lecturers have the highest influence on the success of undergraduate students in construction related disciplines in Nigerian while school board members have the lesser impact. Concentration, lack of reading habit and class size are the major identified factors affecting the performance of undergraduates. The study therefore recommended that parents and lecturers should be made aware of their roles in the success of their wards while necessary facilities in term of accommodation and serene environment on campus should be provided for students as this will enhance students' concentration, hence increasing the rate of students' success.Asikhia (2010) noted that family educational background and socio-economic status influences the academic performance of students in Mathematics.Researchers have concluded that economic hardships that arise in families and which eventually either motivates or derail the learning attitudes of children have roots in the socioeconomic status of parents. Midray and Midray (2011) discovered that families with high income can provide the necessary skills, knowledge, tools and instruments that are needed by the children. Akomolafe and Olorunfemi (2011) showed that family type significantly influenced academic performance of secondary students. A study carried out by Shim, Felner and Shim (2000) showed that the beliefs and attitudes of parents foster the academic success of their children.Mphale and Mhalauli (2014) found out that inadequate resources, lack of teacher's incentives, poor working conditions and lack of parental involvement in school activities as factors which contribute to poor students' academic performance. They revealed that teachers' low morale, teachers' strikes, teachers and students unpreparedness for change, lack of teachers incentives, students not serious with the school work, poor leadership, the examinations not addressing the syllabi objectives and lack of support for students homework have an impact on students' academic achievement and therefore recommended that high teacher's morale, availability of resources and parental involvement are critical for the attainment of high quality education in Botswana secondary schools.

\subsection{School Factors Affecting the Performance of Undergraduate Students in Mathematics}

Data in table 4 indicated generally that the respondents agreed that school factors affect the performance of undergraduate students in Mathematics ( $\mathrm{M}=2.69$; Std. Dev.=1.01). Data in table 4 also revealed that some of the school factors affecting undergraduate students' performance in Mathematics are overcrowding of the teaching time table $(\mathrm{M}=2.92$; Std. Dev. $=1.06)$, impatience in examination supervision by examiners $(\mathrm{M}=2.77$; Std. Dev. $=1.03)$, too many course offering in the school curriculum ( $M=2.75$; Std=1.01), poor study and learning environment ( $M=2.72$; Std. Dev. $=0.99)$, poor orientation by the school on gaining admission $(\mathrm{M}=2.71$; Std. Dev. $=0.97)$, excessive workload given to the students by the school management $(\mathrm{M}=2.68$; Std. Dev. $=1.00)$, excessive financial demands on parents by the school management ( $\mathrm{M}=2.68$; Std. Dev. $=1.00)$, overcrowding of the examination time table $(\mathrm{M}=2.66$; Std. Dev. $=0.96)$ and poor management of government libraries and laboratories $(\mathrm{M}=2.64$; Std. Dev.=1.01). Data in table 10 showed that there is an insignificant positive relationship between school factors and undergraduate student performance in Mathematics $\left(\mathrm{F}_{(1,247)}=1.438\right.$, $\mathrm{p}>0.05 ; \mathrm{r}=0.08$ ). Data in table 10 also revealed that the school factors affect undergraduate students' Mathematics performance by $0.6 \%$.

Olatunji, Aghimien, Emmanuel and Olushola (2016) revealed that parents and lecturers have the highest influence on the success of undergraduate students in construction related disciplines in Nigerian while school board members have the lesser impact. Concentration, lack of reading habit and class size are the major identified factors affecting the performance of undergraduates. Thomas and Amaechi (2019) found out that to high extent school buildings, technical workshop library facilities, and location of school influences students' academic performance in technical colleges in Rivers State. Onyara (2013) revealed that physical resources are not well developed in most of the secondary schools in Teso South District of Kenya which affects the performance of students.

\subsection{Governmental Factors Affecting Undergraduate Students' Performance in Mathematics}

Data in table 5 indicated generally that the respondents agreed that government factors affect the performance of undergraduate students in Mathematics $(M=2.63$; Std. Dev. $=1.02)$. Data in table 5 also revealed that some of the governmental factors affecting undergraduate students' performance in Mathematics are inadequate employment of qualified Mathematics lecturers ( $M=2.88$; Std. Dev.=0.89), absence of learning materials $(M=2.74$; Std. Dev. $=1.03)$, lack of instructional materials $(\mathrm{M}=2.70$; $\mathrm{Std}=1.05)$, dilapidated structures or buildings $(\mathrm{M}=2.69$; Std. $\mathrm{Dev} .=1.01)$, lack of Mathematics laboratory $(\mathrm{M}=2.66$; Std. $\mathrm{Dev}=0.99)$, poor supervision, monitoring and management of public schools $(\mathrm{M}=2.65$; Std. Dev=1.05), lack of infrastructures $(\mathrm{M}=2.64$; Std. Dev.=1.04), undue interference on academic calendar by

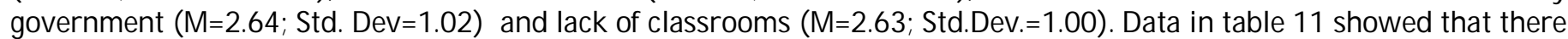
is an insignificant positive relationship between governmental factors and undergraduate student performance in Mathematics $\left(\mathrm{F}_{(1,247)}=0.615, \mathrm{p}>0.05 ; \mathrm{r}=0.05\right)$. Data in table 11 also revealed that governmental factors affect undergraduate students' Mathematics performance by $0.2 \%$. 
Thomas and Amaechi (2019) found out that to high extent school buildings, technical workshop library facilities, and location of school influences students' academic performance in technical colleges in Rivers State. It was recommended among others, that adequate and conducive classroom building be provided in the public schools to help promote effective teaching for students' improved academic achievement. The study also recommended that technical workshop and library facilities be provided in technical colleges in Rivers State. Mphale and Mhalauli (2014) found out that inadequate resources, lack of teacher's incentives, poor working conditions and lack of parental involvement in school activities as factors which contribute to poor students' academic performance. They revealed that teachers' low morale, teachers' strikes, teachers and students unpreparedness for change, lack of teachers incentives, students not serious with the school work, poor leadership, the examinations not addressing the syllabi objectives and lack of support for students homework have an impact on students' academic achievement and therefore recommended that high teacher's morale, availability of resources and parental involvement are critical for the attainment of high quality education in Botswana secondary schools.

\subsection{Relationship between the Factors and Undergraduate Students' Performance in Mathematics}

Data in table 6 showed that there is a positive relationship between the lecturer, student, parent, government and school factors and undergraduate students' performance in Mathematics $(r=0.14)$. Data in table 12 showed that there is a significant positive relationship between the lecturer, student, parent, government and school factors and undergraduate students' performance in Mathematics $\left(\mathrm{F}_{(1,247)}=4.873, \mathrm{p}<0.05 ; \mathrm{r}=0.14\right)$. Data in table 12 also revealed that the factors account for only $1.9 \%$ effect on undergraduate students' performance in Mathematics. Mphale and Mhalauli (2014) found out that inadequate resources, lack of teacher's incentives, poor working conditions and lack of parental involvement in school activities as factors which contribute to poor students' academic performance. They revealed that teachers' low morale, teachers' strikes, teachers and students unpreparedness for change, lack of teachers incentives, students not serious with the school work, poor leadership, the examinations not addressing the syllabi objectives and lack of support for students homework have an impact on students' academic achievement and therefore recommended that high teacher's morale, availability of resources and parental involvement are critical for the attainment of high quality education in Botswana secondary schools. Olatunji, Aghimien, Emmanuel and Olushola (2016) revealed that parents and lecturers have the highest influence on the success of undergraduate students in construction related disciplines in Nigerian while school board members have the lesser impact. Concentration, lack of reading habit and class size are the major identified factors affecting the performance of undergraduates. The study therefore recommended that parents and lecturers should be made aware of their roles in the success of their wards while necessary facilities in term of accommodation and serene environment on campus should be provided for students as this will enhance students' concentration, hence increasing the rate of students' success.

\section{Conclusion}

The study identified some of the lecturer, student, parent, school and government factors affecting undergraduate student performance in Mathematics. The study found out that lecturer, student and parental factors have significant positive relationship while school and governmental factors have insignificant but positive relationship with undergraduate students' performance in Mathematics. Generally, there is a significant positive relationship between the lecturer, student, parent, government and school factors and performance with the factors accounting for $1.9 \%$ contribution to undergraduate students' performance in Mathematics.

\section{Recommendations}

- Mathematics lecturers should improve their teaching qualification, develop positive attitude towards teaching students to understand concepts, adapt effective teaching methods and techniques, regularly go for lectures, lecture with appropriate instructional materials, show commitment by effectively preparing for lectures and efficiently teaching and evaluating students to achieve optimal learning outcome.

- Undergraduate Mathematics students should avoid absenting from lectures, regulate their involvement in emotional relationships, develop positive student-lecturer relationship, collaboratively learn, do assignments given by the lecturers, avoid examination malpractice, develop good study habit and work hard to obtain good grade at graduation.

- Parents should be involved in their children academics by guiding, adequately funding, supporting and encouraging them to reach their goals in Mathematics education.

- The school management should avoid overcrowded teaching and examination time table, ensure proper examination supervision with examinees allowed the time for the examination, reduce the course load, provide a good study and learning environment, organize proper orientation for new intakes, demand affordable school fees and guarantee effective use and management of school libraries and laboratories.

- The government should adequately employ qualified Mathematics lecturers, provide adequate learning materials, renovate and build new infrastructures such as classrooms, lecture halls, Mathematics laboratories and libraries with proper supervision, monitoring and management of public schools.

- The government and the school management should effectively manage the lecturers, students and collaborate with the parents to ensure improved undergraduate students' performance in Mathematics. 


\section{References}

i. Akomolafe, M. J. \& Olorunfemi-Olabisi, F. A. (2011). Impact of family type on secondary school students' academic performance in Ondo State, Nigeria. European Journal of Educational Studies, 3(3), 481-487. Retrieved September 29, 2020 from https:/ / d1wqtxts1xzle7.cloudfront.net/ 31087377/ \%285\%29ejes_156_Jude_gel.tar.22__A_ubat_2011_paid.pdf?1 $365134110=$ \&response-contentdisposition=inline\%3B+filename\%3DIMPACT_OF_FAMLL_TYPE_ON_SECONDARY_SCHOO.pdf

ii. Anderson, S. (2015). How parental involvement makes a difference in reading performance. Reading improvement, 37(2), 61-86.

iii. Asikhia, O.A. (2010).Students and teachers' perception of the causes of poor academic performance in Ogun State secondary schools [Nigeria]: Implications for couselling for national development. European Journal of Social Sciences, 13(2), 229-242. Retrieved September 29 from https:/ / www.researchgate.net/ publication/ 289769514 Students and teachers\%27 perception of the causes 0 f_poor_academic_performance in_ogun_state_secondary_schools_Nigeria Implications_for_couselling_for_nation al development.

iv. Department of Mathematics in the Universities (2019). Student enrollment statistics.

v. Federal Republic of Nigeria (2014). National policy on education ( $6^{\text {th }}$ ed.). Lagos, NERDC.

vi. Harb, N. \& El-Shaarawi, A. (2006). Factors affecting students' performance. Retrieved September 29, 2020 from https:// www.researchgate.net/ publication/24112529_Factors_Affecting_Students' Performance

vii. Midray, S. \& Midray, J. (2011). Parental involvement and gräe four students' Ārabic reading performance. European Journal of Educational Studies3(2), 245-260. Retrieved September 29, 2020 from https:/ / www.researchgate.net/ profile/ Sadiq Midraj/ publication/ 265892855 PARENTAL INVOLVEMENT AND GRADE FOUR STUDENTS' ARABIC READING ACHIEVEMENT/ links/ 5b0dffc3̄0f7e9b1ed7012aa3/ PARENTALINVOLVEMENT-AND-GRADE-FOUR-STUDENTS-ARABIC-READING-ACHIEVEMENT.pdf

viii. Mphale, L. M. \& Mhalauli, M. B. (2014). An Investigation on students' academic performance for junior secondary schools in Botswana. European journal of Educational Research, 3(3), 111-127. Retrieved September 29, 2020 from https:/ / files.eric.ed.gov/ fulltext/ EJ1086046.pdf

ix. Nyadanu, S.D., Garglo, M.Y., Adampah, T. \& Garglo, R. L. (2014). The impact of lecturer-student relationship on self-esteem and academic performance at higher education. Journal of Social Science Studies, 2(1), $264-81$. Retrieved September 29, 2020 from https:/ / www.researchgate.net/ publication/ 315340930 The Impact_of Lecturer-Student_Relationship_on_SelfEsteem and Academic Performance at Higher Education/ link/ 5a8d 6 c $\overline{4} 6$ a6fdcc6e97142 $\bar{d} /$ download

x. Okello, N. P. (2014). Peer interactions and positive student-lecturer relationship as a tool for improving the teaching and learning of college algebra: A case study at USIU. Journal of Language, Technology \& Entrepreneurship in Africa, 5(1), 70-87.

xi. Olatunji, S. O., Aghimien, D. O., Emmanuel, A. \& Olushola, O. E. (2016). Factors affecting performance of undergraduate students in construction related disciplines. Journal of Education and Practice, 7(13), 55-62. Retrieved September 29, 2020 from https:/ / files.eric.ed.gov/ fulltext/ EJ1102825.pdf

xii. Onyara, B. N. (2013). School based factors influencing student's academic performance at Kenya certificate of secondary education in Teso South District. Unpublished Master's Thesis, University of Nairobi. Retrieved September 29, 2020 from

http:/ / erepository.uonbi.ac.ke/ bitstream/ handle/ 11295/ 56553/ Onyara_School\%20Based\%20Factors\%20Infl uencing $\% 20$ Student $\%$ e2\%80\%99s\%20Academic\%20Performance $\% 20$ At $\% 20$ Kenya $\% 20$ Certificate $\% 20$ Of $\% 20$ Secondary\%20Education\%20In\%20Teso\%20South\%20District.pdf?sequence=3\&isAllowed=y

xiii. Shim, M.K., Felner, R.D. \& Shim, E, (2000). The effect of family structures on academic performance. Eric-Institute of Education Sciences: Rhode Island.

xiv. Thomas, C. G. \& Amaechi, O. J. (2019). Influence of school environment on students' academic performance in Technical Colleges in Rivers State. International Journal of New Technology and Research (IJNTR), 5(3), 40-48. Retrieved September 29, 2020 from https:/ / d1wqtxts1xzle7.cloudfront.net/ 58767555/ IJNTR05030036.pdf

xv. Waseke, E.L., Enose, M.W., Simatwa \& Okwach, T.O. (2016). Influence of teacher factor on students' academic performance in secondary school education: A case study of Kakamega County, Kenya. Greener Journal of Educational Research, 6(4),151-169. Retrieved September 29, 2020 from http:/ / www.gjournals.org/ GJER/ archive/ june-2016-vol-64/ waseka-et-al.html

xvi. Wonu, N. \& Zalmon, I. G. (2019). Constraints to instructional effectiveness and undergraduate student Mathematics learning achievement. International Journal of Advanced Education and Research, 4(6), 54-65.

xvii. Xiao, J. \& Wilkins, S. (2015). The effects of lecturer commitment on student perceptions of teaching quality and student satisfaction in Chinese higher education. Journal of Higher Education Policy and Management, 37(1), 98110. Retrieved September $\quad 29, \quad 2020$ from https:/ / www.tandfonline.com/ doi/ abs/ 10.1080/ 1360080X.2014.992092 